\title{
WASTE DUMPS IN LATVIA: FORMER LANDFILLING, CONSEQUENCES AND POSSIBLE RE-CULTIVATION
}

\author{
Burlakovs Juris $^{\mathrm{a}^{*}}$, Vircavs Magnuss ${ }^{\mathrm{a}}$ \\ ${ }^{a}$ Faculty of Geography and Earth Sciences, University of Latvia, Alberta Street 10, Riga, LV-1010, Latvia \\ *phone+37128469044, fax+37167801703, email: jurisb@vkb.lv
}

\begin{abstract}
Waste and the pollution of ecosystems are direct consequences of the use of resources for the modern society development. Waste dumps are evident witnesses of former economic and industrial management without sustainable waste management planning.

Particular attention in this article is paid to the research of two waste dumps in the capital city of Latvia - Riga, which are planned to be re-cultivated in the nearest future and one site, which is former toxic hazardous soil dump site, where the remediation of site is of priority need. Waste dumps, mentioned in the article below, were created without environmental planning and in many cases the location of waste dumps are very problematic for secondary use of dumped material, remediation and re-cultivation. The present study is giving a general overview of contamination level in two waste dumps in Riga, which were made in the period from 50-ties to 70 -ties of the $20^{\text {th }}$ century, also the case of hazardous soil dump site formed in a period of more than 100 years is described. Planned actions as well as direct remediational technologies to reduce the poisonous impact to the urban environment and the role of recultivation in the urban planning in general are proposed.

The fate of contaminants, including heavy metals, macrocomponents, oil products, various chemicals and other chemical oxygen demand (COD) and biological oxygen demand (BOD) agents must be estimated in the process of re-cultivation. Special technologies can be applied such as:

a) in-situ and ex-situ technologies - excavation with separation and concentration of valuable materials, stabilization/ solidification of some areas in site and out of site;

b) in-situ technologies - soil as the infiltrate source flushing for groundwater contamination level diminishing, barriers/ treatment walls around the waste dump areas, chemical treatment and phytoremediation;

c) ex-situ technologies - soil washing and bioremediation in some cases.

Legislative aspects as well as the possible land remediation technologies for reduction of the waste dump generated contamination in Latvia are also discussed.
\end{abstract}

Keywords: dump sites, remediation, re-cultivation

\section{Introduction}

Soil and groundwater are environmental compartments that are primarily influenced by industrial development with increasing amount of industrial wastes and inadequate their dumping. It causes a large number of contaminated sites that are disseminated in post industrialized countries [1; 2]. Environmental contamination as a result of anthropogenic activities is not a recent phenomenon. Contaminated sites can be found in functioning as well as abandoned industrial (brownfield) territories, landfills, residential areas with historical contamination, road sides and rarely in polluted sites by natural activities. Pollution data on its amount and concentrations is known from historical studies and monitoring nowadays, but it should be periodically updated for the use of territorial planning or in case of a change of the land use. A special attention should be paid to the contamination in former dump sites, because in many cases this contamination is most problematic for remediation and is disturbing the territorial planning of cities. 242 territories now are numbered as contaminated and fixed in the National Register of contaminated territories of Latvia, 14 of those can be counted as main in the sense of the amount of contaminants, concentration of those and the priority aspect of the importance to be remediated and re-cultivated.

\section{Legislation}

The Law "On Pollution" (came into force on 1 July, 2001) defines the procedures in the sphere of contamination [3]. The purpose of the Law (Section 2) is to prevent or reduce harm caused to human health, property or the environment due to pollution, to eliminate the consequences of harm caused. A local government in co-operation with the relevant Regional Environmental Board of State Environmental Service has an obligation to ascertain and initially assess polluted and potentially polluted sites in a relevant administrative territory (Section 33). The Ministry of Defense has to ascertain and initially assess polluted territories in its possession and notify the relevant local government and regional environmental board thereof (Section 34).

Methods and procedures for the ascertaining of polluted and potentially polluted sites, as well as the procedures 
for financing, conditions for data collection and utilization are regulated by the Cabinet of Ministers Regulations No 483 adopted on November 20, 2001 "Inventory and registration of contaminated and potentially contaminated areas" [4].

Latvian Environmental, Geological and Meteorological Centre (supervised institution of Ministry of Environmental Protection and Regional Development, MEPRD) has an obligation to maintain all collected and processed information about contaminated sites.

The main legislative Act at the moment in Latvia is the State Waste Management Plan 2006-2012 [5], which is issued based on several Directives of the European Union, such as 75/442/EEK on Waste [6], 91/689/EEK on Hazardous Waste [7] and several other Directives on specific kind of wastes. Most important topics in this management plan is to prevent the formation of waste, guarantee that the waste is not hazardous to health and environment, promotion of the reuse and recycling of useful material, minimizing the amount of waste and processing as close as possible to places of generating of the waste. The organizing of waste management should contain such demands in a priority queue:

1. Causes of waste formation must be diverted, including the implementation of clean technologies;

2. Reduction of the amount of waste and hazardousness;

3. Waste must be reused and recycled as much as possible;

4. Waste must be landfilled in a relevant way, in order to guarantee the safety for environment and health of people;

5. Dump sites must be closed in an appropriate way, also the re-cultivation of closed dump sites and polygons must be guarantee according the Waste Management Plan.

Latvia is divided in 10 waste management regions, one of separate regions is the Great Riga region. The Great Riga region has individual Riga Waste Management plan 2006-2012 [8].

Law "On Waste Management" [9] is regulating the management of waste on legislative base, it is in force from 01.01.2011. The aim of the law is to adopt the requirements of new Directive 2008/98/EC [10] in the legislation of Latvia. Draft law states the measures to encourage the options that deliver the best overall environmental outcome, including specific waste streams departing from the hierarchy where this is justified by life-cycle thinking on the overall impacts of the generation and management of such waste. It also states that the first objective of any waste policy should be to minimize the negative effects of the generation and management of waste on human health and the environment. Waste policies and waste management plans should be renewed because of the administrative reform. According to this Law the waste is divided in two main groups: hazardous and municipal waste. Hazardous waste is defined as the waste which has one or more hazardous property, which is making those hazardous for environment or human health. All other waste is classified as the municipal waste. The law says that collecting, sorting, storing, transport, landfilling or recycling of waste must be done only at special places defined by legislation. The responsibility on waste management in regions is taken by the municipalities.

Waste Management Law tells that the management must be done according the State Waste Management plan, Regional waste management plans and norms issued by local municipalities.

\section{Dump Sites in Latvia}

Former dump sites of mixed waste can be composed of hazardous waste as well as all other types of waste. In the former USSR, various kind of municipal, residential and construction waste as well as hazardous substances and materials were often dumped in these dump sites. Table 1 shows the main contaminated dump sites, type of contamination as well as probable recommendations for remedial actions in these sites in Latvia, numbers in the table correspond to numbers in Figure 1, where the geographic location is given.

Especially hazardous sites must be counted separately, e.g. liquid toxic substances dump site in Jelgava (mostly groundwater contamination), biomedical and chemical industry dump site (Olaine), former treatment facilities of the city Riga and similar ones. Sites mentioned further are the most important which must be remediated and re-cultivated at the end. After all these actions the risk assessment for ecological threats must be done. Several sites mentioned in the table are described in a more detailed way, some of those has had assessment of threats to environment and given recommendations for the type of remediation to use. Case studies for more detailed research are described for two former "municipal waste" sites - Deglava and Kleisti Dumps, which were used for disposal of various type of waste in 50-ties to 70 -ties of $20^{\text {th }}$ century, also the example of "BLB Baltijas Terminal" territory is given - hazardous soil dump site formed in a period of more than 100 years. 


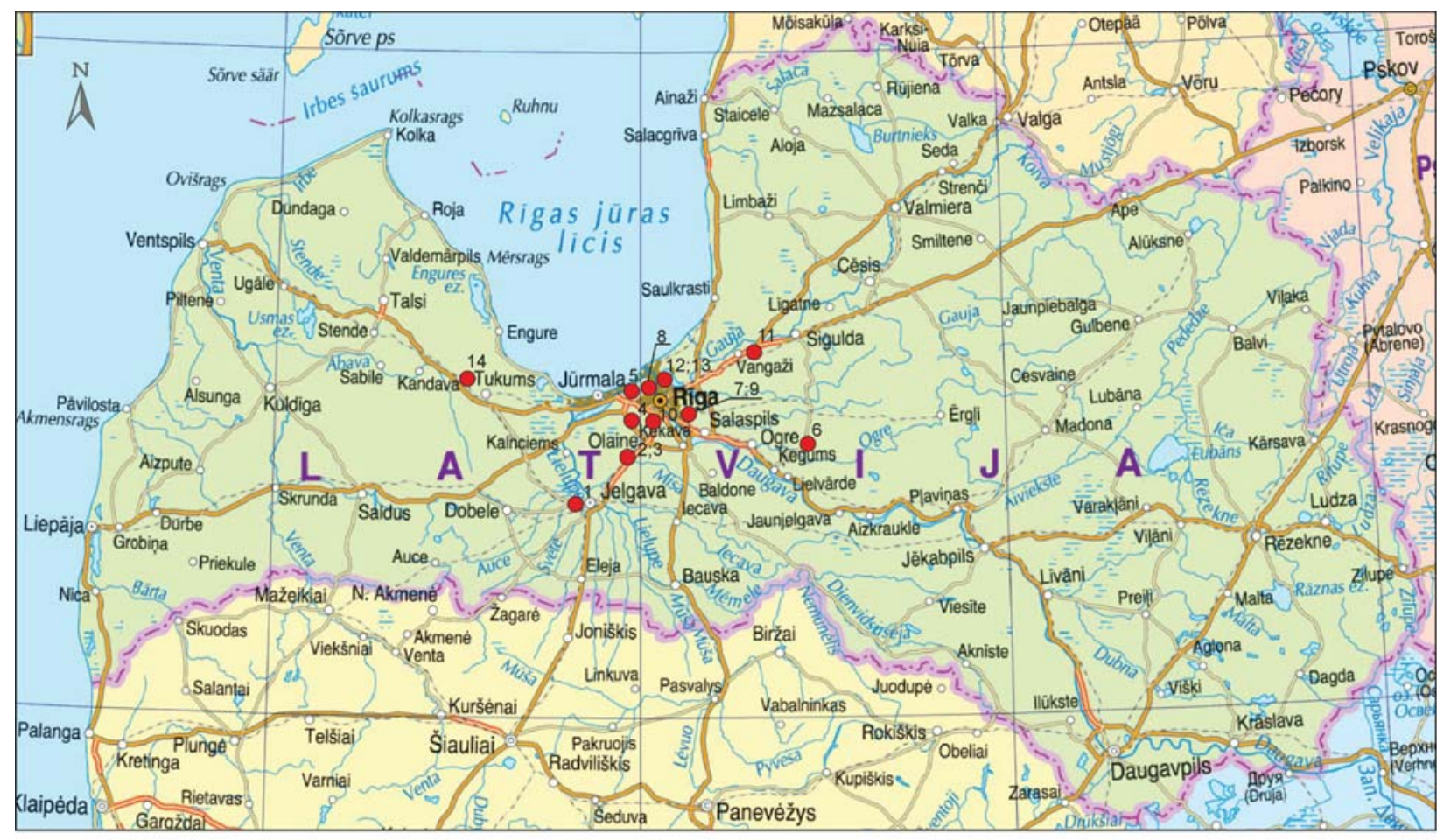

Figure 1. List of main contaminated dump sites

Liquid toxic substances dump site in Jelgava (nr.1) was used for almost 40 years and the history of this dump site can be divided in 3 parts: 1) solid waste disposal (1951-1969); 2) liquid toxic waste disposal (1970-1989); 3) uncontrolled periodic disposal (1990-2005). Now this dump site is included in the priority list of remedial sites in Latvia and detailed research has been done in 2005 and 2008. Contamination of groundwater with heavy metals, nitrates, chlorides are unacceptable, exceeds norms and must be treated. Recommended technologies for treatment would be pump-and-treat groundwater remediation technology, also the possible way would be the treatment by passive wall or reactive wall technologies with soil stabilization/solidification in some most contaminated sectors. Most toxic for the environment are heavy metals, but the complex contamination of groundwater is one of the highest in Latvia concentration of chlorides in groundwater exceed $7500 \mathrm{mg} / \mathrm{l}$, sulfates $>1200 \mathrm{mg} / \mathrm{l}$. Contamination is distributed in area of $23 \mathrm{ha}$, the depth of the plume reaches $12 \mathrm{~m}$. [12]

Two sites of toxic liquid hazardous substances are in Olaine (nr.2;3), where the contamination of $2500 \mathrm{~m}^{3}$ liquid and $4000 \mathrm{~m}^{3}$ solid wastes are found up to $12 \mathrm{~m}$ of depth. Main substances are pyridine, butanol, isopropyl alcohol, chlorides and ammonia. Maximum concentrations of those in groundwater exceed $4500 \mathrm{mg} / 1,3200 \mathrm{mg} / 1,1400 \mathrm{mg} / \mathrm{l}$, $1400 \mathrm{mg} / \mathrm{l}$ and $3000 \mathrm{mg} / \mathrm{l}$ sequentially. Contamination is widely distributed in area of $45 \mathrm{ha}$ and is polluting groundwater and surface water further. Treatment technologies could be used similar as in the previous case in Jelgava - reactive walls, pump-and-treat and soil flushing in most contaminated parts. [13]

Inčukalns Southern and Northern goudron ponds (acid tar lagoons) (nr.11) are historical contaminated sites located 30-35km from Riga. During 1950-1980 goudron was waste generated as the result of medical and perfumery oil production. Disregarding environmental protection measures goudron and other chemical waste was dumped in a sandy pit in a foresed area. In 1986 the dump site was closed. Considering permeable and percolation sandy layers contamination reached groundwater and artesian waters in the depth of 70-90m by infiltration. In 2010 a remediation project of the Inčukalns goudron ponds began, the main task of which is to prevent contamination of the territories alongside with goudron ponds. Project implementation will include treatment with lime and replacement, excavation and disposal to landfill (with or without treatment) and un-engineered capping as well as pumping out the contaminated waters, then treating and injecting it back into the subterranean in order to stop mobility of the contaminated plume. Otherwise contaminated plume together with the groundwater flow will reach the river Gauja horizon. Strong precautions will be taken during excavation and neutralization works in respect to air emissions, behaviour of tar and its ingredients in the soil and groundwater. The remediation in Inčukalns will demand multidisciplinar approach in order to have the successful result. The gudron in ponds and in the soil has complicated chemical properties, therefore, similar case studies abroad should be used for application in the Republic of Latvia. The sandy layers, in which goudron is placed in, are permeable and have good filtration properties, what means, that there is a deal with potential hazard in closest 25 years, if the movement of contamination plume in groundwater will not be stopped to the river Gauja. The main idea is to stop 
the plume with pumping out the polluted waters, then treating and injecting back into the subterranean. Soil flushing may be applied to reduce the impact of long migrated contamination plume. Environmental impact and monitoring of it should be made using previous knowledge in other case studies. Air emissions as well as behavior of tar and its ingredients in soil and groundwater during excavation and neutralization works must be strongly taken in account. The legislation and funding should be taken in account while planning any time of remediational activities, also emissions and residuals during works must be utilized under the strong control.

Table 1

List of Main Contaminated Dump Sites, Type of Contamination and Recommendations for Probable Remedial Actions [11]

\begin{tabular}{|c|c|c|c|}
\hline No & Location, name & Type of contamination & $\begin{array}{c}\text { Recommendations for probable } \\
\text { remediation actions }\end{array}$ \\
\hline 1. & $\begin{array}{l}\text { Liquid toxic substances dump, } \\
\text { Jelgava }\end{array}$ & $\mathrm{HM}^{1}, \mathrm{EAF}^{2}, \mathrm{OP}^{3}$ & $\begin{array}{l}\text { Groundwater treatment technologies, soil } \\
\text { flushing, reactive walls }\end{array}$ \\
\hline 2. & $\begin{array}{l}\text { "BIOLAR" dump of toxic } \\
\text { substances, Olaine, }\end{array}$ & $\begin{array}{l}\text { Toxic hazardous substances, } \\
\text { HM }\end{array}$ & $\begin{array}{l}\text { Groundwater treatment technologies, soil } \\
\text { flushing, reactive walls }\end{array}$ \\
\hline $3-$ & Olaine dump site & Heavy metals & $\begin{array}{l}\text { Risk assessment, monitoring, re-cultivation, } \\
\text { soil amendments }\end{array}$ \\
\hline 4. & Mārupe Landfill & $\mathrm{COD}^{4}, \mathrm{~N}, \mathrm{P}$ & Risk assessment, monitoring, re-cultivation \\
\hline 5. & Priedaine dump site & COD, ammonia, OP, HM, N & $\begin{array}{l}\text { Risk assessment, monitoring, re-cultivation, } \\
\text { reactive walls }\end{array}$ \\
\hline 6. & Ķilupe Landfill, Ogresgals & $\mathrm{COD}, \mathrm{EAF}, \mathrm{N}$ & $\begin{array}{l}\text { Risk assessment, monitoring, re-cultivation, } \\
\text { reactive walls }\end{array}$ \\
\hline 7. & Getliņi Landfill, Riga & EAF, N, COD & $\begin{array}{l}\text { Risk assessment, monitoring, reactive } \\
\text { walls, soil flushing }\end{array}$ \\
\hline 8. & Kleisti dump site, Riga & $\begin{array}{l}\mathrm{HM}(\mathrm{Zn}, \mathrm{Pb}, \mathrm{Cr}), \mathrm{COD}, \mathrm{N}, \\
\text { EAF }\end{array}$ & $\begin{array}{l}\text { Risk assessment, monitoring, re-cultivation, } \\
\text { reactive walls, groundwater treatment } \\
\text { technologies, soil amendments }\end{array}$ \\
\hline 9. & Deglava Street dump site & $\mathrm{COD}, \mathrm{N}, \mathrm{V}, \mathrm{EAF}$ & $\begin{array}{l}\text { Risk assessment, monitoring, re-cultivation, } \\
\text { reactive walls, groundwater treatment } \\
\text { technologies, soil amendments }\end{array}$ \\
\hline 10. & $\begin{array}{l}\text { Biek̦engrāvis, former } \\
\text { hazardous waste dump }\end{array}$ & $\mathrm{COD}, \mathrm{OP}, \mathrm{N}, \mathrm{HM}(\mathrm{Cu})$ & $\begin{array}{l}\text { Environmental contamination assessment, } \\
\text { groundwater treatment technologies }\end{array}$ \\
\hline 11. & $\begin{array}{l}\text { Inčukalns Goudron Ponds - } \\
\text { Southern and Eastern (2 sites) }\end{array}$ & OP, EAF, COD & $\begin{array}{l}\text { Groundwater treatment technologies, soil } \\
\text { flushing }\end{array}$ \\
\hline 12. & $\begin{array}{l}\text { Gas Station near } \\
\text { Sarkandaugava Ditch }\end{array}$ & OP & $\begin{array}{l}\text { Groundwater treatment technologies, soil } \\
\text { washing }\end{array}$ \\
\hline 13. & BLB Baltijas Terminal & $\mathrm{HM}, \mathrm{OP}$ & Solidification/stabilization, risk assessment \\
\hline 14. & $\begin{array}{l}\text { Hazardous Waste Dump Site in } \\
\text { Zvāre quarry (Tukums area) }\end{array}$ & $\mathrm{OP}$ & $\begin{array}{l}\text { Groundwater treatment technologies, soil } \\
\text { washing }\end{array}$ \\
\hline
\end{tabular}

In autumn 2010 the promotion of two great scale stabilization/solidification projects were started in the sites of Liepāja and Riga ports. These projects should be viewed as the pilot ones for further development of remediation works in Latvia. The use of the stabilization / solidification $(\mathrm{S} / \mathrm{S})$ technology is not the only solution for the remediation and immobilization of toxic compounds; the further research might be done to draw a sketch for the use of other heavy metal remediation technologies, but the case study, described below has improved that $\mathrm{S} / \mathrm{S}$ technology still would be one of most effective for active and former industrial territories, because stabilized areas does not threat the environment around and also can be used for industrial construction use in future. The present study in the former hazardous soil dump site describes preliminary research before the use of this technology. This site is situated in Riga, Jaunmīlgrāvis - BLB Baltijas Terminal (nr.13) - it is economically active from the beginning of the $20^{\text {th }}$ century. In earlier years (1894-1967) the territory was used for several industrial purposes including the manufacturing of superphosphates, but just nearby the dump site for tailings was made. Later in this area the oil product storage, reloading and transit terminal was founded. In 60 -ties of the $20^{\text {th }}$ century the factory-workshop was functioning, but later the oil product terminal facility overtook 
the area. Soil pollution source mainly was superphosphate production waste (slag), where the highest concentration was received for lead, copper, zinc and arsenic. Total amount of toxic heavy metals throughout the whole research area was estimated $1264 \mathrm{t}$ or $15 \mathrm{~kg} / 1 \mathrm{~m}^{2}$ of slag or: $755 \mathrm{t}$ of copper, lead $85 \mathrm{t}$, zinc $358 \mathrm{t}$, $66 \mathrm{t}$ of arsenic. [14]

Stabilization / solidification technologies are based on the treatment of contaminated soils with materials such as cements and siliceous pozzolans and it can be employed in situ or to the excavated material. As a result, the mobility of the contaminant is reduced by physical-chemical processes. Solidification of the polluted substrate with cement restricts its contact with groundwater and air. Cement and siliceous pozzolans react with metals and cause the formation of hydroxides, carbonates and silicates of very low solubility. This treatment is not efficient for heavy metals that form soluble hydroxides or anions species. It should be emphasized that the mixing process and the heat generated by cement hydration reaction can increase the vaporization of organic pollutants. [15]

$\mathrm{S} / \mathrm{S}$ technologies have been used for decades as the final treatment step prior to the disposal of both radioactive and chemically hazardous wastes. The stabilization refers to an alteration of waste contaminants to a more chemically stable form, thereby resulting in a more environmentally acceptable waste form. Typically, the stabilization processes also involve some form of physical solidification. [16] The preliminary study before the start of remediation was done in the Terminal territory and it gave results of leaching tests for experimentally solidified average soil samples, thus the perspective use of the S/S technology was approved.

Table 2

BS EN 12457-2 leaching test results compared to soil contamination (mg/kg). [17]

\begin{tabular}{|l|c|c|c|c|c|}
\hline Parameter & $\begin{array}{c}\text { Soil contamination } \\
\text { in sample for S/S } \\
\text { testing }\end{array}$ & $\begin{array}{c}\text { Zero sample } \\
\text { (pH level 3,2) }\end{array}$ & $\begin{array}{c}\mathbf{5 \%} \text { cement } \\
\text { (pH level 10,5) }\end{array}$ & $\begin{array}{c}\text { Acceptable } \\
\text { 13\% cement } \\
\text { (pH level 10,5) }\end{array}$ & $\begin{array}{c}\text { leaching level } \\
\text { after the use of S/S } \\
\text { method (Finland) }\end{array}$ \\
\hline $\mathrm{As}$ & 350 & 0,02 & 0,02 & 0,08 & 0,5 \\
\hline $\mathrm{Cd}$ & 2,3 & 0,27 & $<0,002$ & 0,002 & 0,02 \\
\hline $\mathrm{Cr}$ & 13 & $<0,01$ & 0,03 & 0,01 & 0,5 \\
\hline $\mathrm{Cu}$ & 2100 & 600 & 0,25 & 0,27 & 2 \\
\hline $\mathrm{Hg}$ & 0,54 & $<0,002$ & $<0,002$ & $<0,002$ & 0,01 \\
\hline $\mathrm{Ni}$ & 8,1 & 0,65 & $<0,01$ & $<0,01$ & 0,4 \\
\hline $\mathrm{Pb}$ & 400 & 0,02 & $<0,01$ & $<0,01$ & 0,5 \\
\hline $\mathrm{Zn}$ & 1200 & 36 & 0,04 & 0,03 & 4 \\
\hline
\end{tabular}

Leaching test [18] for solidified samples has shown that "zero sample" is leaching out unacceptable amounts of heavy metals $-\mathrm{Cd}, \mathrm{Cu}, \mathrm{Ni}$ and $\mathrm{Zn}$, but in the stabilized solidified form leaching is diminished and are at the acceptable level. Besides, the emission of cadmium and nickel leaches more even the total amount is under the acceptable level. The results show that $\mathrm{S} / \mathrm{S}$ remediation technology has high efficiency on heavy metals, which are most important contaminants in the former hazardous soil dump site.

Deglava and Kleisti waste dumps in Riga (nr.8;9). Riga Development Plan 2006-2018 [19] says that old former dump sites must be remediated and re-cultivated according environmental legislation, thus two cycles of research were done for each of these dump sites. Examinations of studies indicated that the most contaminated parts are the soft dry waste layer and the water saturation (infiltrate) under the waste layer. Dry waste layer in both dump sites is seen to have very strong heavy metal pollution, but leachate - a high content of heavy metals and organic substances, including petroleum products. Also concentration of total nitrogen, nitrogen compounds, total phosphorus, chlorides, sulfates were detected, as well as indicative parameters of COD and BOD. Additionally microbiological analysis was done (Escherichia coli, total coliforms, microbial colonies and enterococci).

The research was done in order to assess how much waste must be removed and what environmental impact remedial and re-cultivation actions will have. Deglava Dump site was researched in 2010, but Kleisti Dump site - started in summer 2011 and was finished in October 2011 [20;21].

Research Stage. Drilling sites in both studies were chosen after careful analysis of historical research study materials. Drilling works were done with Fraste ,Terra - in” and "Iveco” drilling machines. The auger drilling method has been chosen, and boreholes 1-12 m of depth were drilled, including those done through the waste. Temporary monitoring wells were input in sites around and on the dump hill sites. Groundwater sampling and further analysis of possible contamination parameters were done.

Surface waters, sediments from ditches were sampled in closest area around these two dump sites on indicative parameters. The odor testing was done for the air sampled from the waste massif, in order to quantify the possible smell emissions while works of re-cultivation would be done. Emissions and gases were calculated based on the U.S. Environmental Protection Agency developed model LandGEM (Landfill Gas Emission Model - Version 3.02.). [22] 
LandGEM calculations are used for household waste decomposition rate of the first order equation which takes into account the decomposition of waste disposed in municipal solid waste landfills. This program provides a relatively simple approach gases emissions assessment. Models developed in the U.S. dumps empirical observation basis. The model adopted in the data may instead be placed in the field observations.

Planning Stage. The waste from these two sites is planned firstly to be transferred to another part of the dump. One part of the waste, which is the so-called dry waste (the thickness varies from $2-11 \mathrm{~m}$ ) can freely be moved to other parts of the dump, after what all must be sorted, useful compounds recycled and the remained part remediated using technologies of separation and concentration of elements by particle size and magnetic properties. The remaining mass of the waste, if it does not contain hazardous components, which are exceeding legislative values, can be used for filling the ground where excavation works will be done and soil removed also from below the groundwater level. It is necessary to practice the lowering of groundwater by pumping system of wells. After a very rough estimate, lowering the water level should be an average of 1-2 m, biodegradable leachate together with the ground water will reach 100 000 to $300000 \mathrm{~m}^{3}$ at each of sites. Averagely a day each pumping well can pump out around $200 \mathrm{~m}^{3}$ of groundwater in combination with leachate. If there are many, such a huge volume of water and leachate must be directed to the city sewerage system only after additional treatment, because research was carried out and groundwater and leachate analysis results have shown that certain characteristics of chemical concentration exceeds the Latvian legislation set out criteria for groundwater contamination.

\section{Recommendations for Re-Cultivation.}

After these "hills" will meet up environmental expectations after remediation procedures, those should be covered to prevent the infiltration of precipitation and stop the waste pollutant runoff from the waste. Preferably is to cover the waste with sandy loam, organic soil and then greening the area. Depending on the planned land use the bearing capacity for the soil must be adjusted in accordance with expectations. Before moving the waste redesigning of drainage system must be done from the dump outgoing leachate. After the re-cultivation a network of groundwater monitoring wells in both areas of former dump sites and surroundings must be developed, where regular monitoring of groundwater will be performed to control the leachate / groundwater quality and flow direction in future. It is recommended to carry out a risk assessment based on a planned regular (2-4 times per year) of groundwater monitoring data, and in addition according to the random selection method should be regularly monitored groundwater quality in farther situated (up to $0,5-1$ $\mathrm{km}$ ) surroundings and residential building areas. Some contaminated areas will remain and those will be detected and mapped after the finishing of the main part of the re-cultivation during the after remedial research. These separate areas can be remediated using several methods, a brilliant example is phytoremediation technology - with the use of plants to remove, destroy or sequester hazardous substances from the environment. In some cases different soil amendments can be used, e.g. where the $\mathrm{pH}$ level of the soil is low and, therefore, mobility of the polluting metals is high. This can be a strong approach for cationic metals, if those are concentrated in the upper part of the soil - these amendments must be chosen after deep evaluation and chemical experiments.

Remaining contamination of areas under the "reprocessed hills" can be diminished by chemical treatment. Chemical processes include reduction of the bioavailability/mobility of heavy metals as well as other contaminants upon chemical reactions with specific reagents. Technologies for heavy metal remediation are based on precipitation, oxidationreduction, and organic-metal complexation reactions that are well known and widely studied technique in chemistry, for example, chemical technology, environmental, analytical, and radioanalytical chemistry. The use of chemical processes has a drawback conjugated with the possible side effects on the environment that has to take into consideration in the choice of the chemical reagents in treatment process [23;24]. Dissolved heavy metals in groundwater can be precipitated out of solution in various insoluble compounds. The most common heavy metal precipitates are hydroxides, sulphides, carbonates, phosphates, oxalates, and some others. Solubility product constant $\left(\mathrm{K}_{\mathrm{sp}}\right)$ of the insoluble compound characterizes perfection of precipitation reaction. Using, for example, phosphate containing precipitating reagent (apatite II) $\mathrm{U}, \mathrm{Pu}$, and heavy metals $(\mathrm{Cu}, \mathrm{Cd}, \mathrm{Pb}$, and $\mathrm{Zn}$ ) are transformed into low-solubility phosphate mineral phase in which they are not bioavailable. Effectiveness is provided due to the extremely low $\mathrm{K}_{\mathrm{sp}}$ value, for example, solubility product constant of $\mathrm{U}$-phosphate (autunite) is $\mathrm{K}_{\mathrm{sp}}=10^{-49}$, and of $\mathrm{Pb}$-apatite (pyromorphite) is $\mathrm{K}_{\mathrm{sp}}=10^{-80}$ [25]. The lower the solubility product constant, the more insoluble the precipitated compound is. Precipitation of insoluble substance causes two another processes: coprecipitation and sorption that occur simultaneously with formation of precipitates. Thereby heavy metals that stand in aqueous media in minor and micro concentrations are also concentrated in solid phase. Precipitation, coprecipitation and sorption are spontaneous processes with tendency of disorder (entropy) decreasing, i.e., contaminants arrive into the solid phase.

\section{Conclusions}

The in situ and ex situ technologies are used for remediation of contaminated sites. The future of dump site remediation in Latvia mostly could be done by S/S, separation / concentration, chemical treatment, soil flushing, phytoremediation technologies or combined. In Latvia the assessment and evaluation of contaminated and potentially contaminated sites began in the 1980s. The National Register of Contaminated Territories (NRCT) covers the territories 
that are contaminated with various materials, inorganic and organic including hazardous and non- hazardous substances. In the NRCT the sites are divided in 3 categories: the first includes 242 contaminated sites, 14 of which can be counted as the main contaminated dump sites in Latvia - former municipal or industrial. Heavy metal remediation in the case study of "BLB Baltijas Terminal" is mostly connected with the treatment of soil and immobilizing of toxic elements in situ - S/S technology is the most appropriate in this case. Leaching test shows that in the stabilized and solidified soil leaching is diminished and is at the acceptable level. It certifies effectiveness of the applied S/S technique for heavy metal (As, $\mathrm{Cd}, \mathrm{Cr}, \mathrm{Cu}, \mathrm{Hg}, \mathrm{Ni}, \mathrm{Pb}$, and $\mathrm{Zn}$ ) remediation in this industrial area. Hazardous soils dump sites often are contaminated with heavy metals, like in case of the Terminal area, thus can be remediated using S/S technology. Leaching tests and economical evaluation has shown that this technology is among the best applicable. Separation/ concentration technologies, chemical treatment, soil washing and groundwater treatment technologies can be applied in remediation of two former municipal waste dumps in Riga: Kleisti and Deglava sites. Remediation of dump sites in the capital city Riga is urgent and important need in the way of the future development.

\section{References}

[1]. Critto A.,Cantarella L., Carlon C., Giove S., Petrzzelli G., Marcomini A.: Decision Support-Oriented Selection of Remediation Technologies to Rehabilitate Contaminated Sites. Integrated Environmental Assessment and Management, 2006, Vol. 2, No3, 273-285.

[2]. Prokop G., Schamann M., Edelgaard I.: Management of contaminated sites in Western Europe. Topic Report. No 13/1999. European Environment Agency, Copenhagen, 2000.

[3]. 15.03.2001. Law “On Pollution” (Par piesārņojumu) (“LV”, 51 (2438), 29.03.2001.; Ziņotājs, 9, 03.05.2001.) [in power from 01.07.2001.]; with Amendments.

[4]. Regulation of the Cabinet of Ministers Nr.483. Identification and Registration of Contaminated and Potentially Contaminated Sites (in Latvian: Piesārṇoto un potenciāli piesārņoto vietu apzināšanas un reǵistrācijas kārtība) ("LV”, 171 (2558), 27.11.2001.) [in power from 28.11.2001.]; with Amendments.

[5]. Regulation of the Cabinet of Ministers Nr.860 On State Waste Management Plan 2006-2012 (in Latvian: Par Atkritumu apsaimniekošanas valsts plānu 2006.-2012.gadam) (“LV”, 210 (3368), 30.12.2005.) [in power from 29.12.2005.]

[6]. Council Directive 75/442/EEC of 15 July 1975 on waste. (with Amendments). Official Journal L 194, 25/07/1975 p. $0039-0041$

[7]. Council Directive 91/689/EEC of 12 December 1991 on Hazardous Waste. Official Journal L 377, 31/12/1991 P. $0020-0027$

[8]. Riga Waste Management Plan 2006-2012. [in Latvian: Rīgas atkritumu apsaimniekošanas plāns] Accessed 15.11.2011. Available: http://www.riga.lv/NR/rdonlyres/49E64F58-76C8-4737-A453-091FA5BE281C/10216/ Rigasplans3.pdf

[9]. 15.03.2001. Law “On Pollution” (in Latvian: Par piesārṇojumu) (“LV”, 51 (2438), 29.03.2001.; Ziṇotājs, 9, 03.05.2001.) [in power from 01.07.2001.]; with Amendments

[10]. Directive 2008/98/EC of the European Parliament and of the Council of 19 November 2008 on Waste and Repealing certain Directives. Official Journal L 312/3, 22/11/2008 p. 3-30

[11]. National Register of Contaminated and Potentially Contaminated Sites (in Latvian: Piesārnoto un potenciāli piesārņoto vietu reǵistrs). LVĢMC. Accessed: 07.04.2011. Available: http://oas.vdc.lv:7779/p_ppv.html

[12]. Jelgava hazardous waste dumpsite. Supplementary investigations. Reports. 1999, 2005, 2008 [unpublished]

[13]. National Programme of Remediation of Historically Polluted Sites. Project. [in Latvian: Nacionālā programma. Vēsturiski piesārņotu teritoriju sanācija]. 15.12.2006. Available: http://www.vidm.gov.lv/lat/finansu_ instrumenti/kohez/files/text/finansu_instrumenti/koh_f/nac_prog_2007_2013//NP_piesarnojums.pdf

[14]. Ekohelp Ltd.: Report on Contamination Monitoring and Remediation (heavy metals), 2009 [in Latvian, unpublished]

[15]. Lombi E., Wenzel W.W., Adriano D.C.: Soil Contamination, Risk Reduction and Remediation. Land Contamination \& Reclamation, 6 (4), 1998, 183-197.

[16]. Shi C., Fernandez-Jimenez A.: Stabilization / Solidification of Hazardous and Radioactive Wastes with Alkaliactivated Cements. Journal of Hazardous Materials, B137, 2006, 1656-1663.

[17]. Europroject Ltd.: Report on Contamination Research and Technical Economic Planning (heavy metals), 2010 (in Latvian, unpublished)

[18]. BS EN 12457-2:2002. Characterisation of waste. Leaching. Compliance test for leaching of granular waste materials and sludges.

[19]. Riga Development Plan 2006-2018. [in Latvian: Rīgas attīstības plans 2006-2018]. Available: http://www.rdpad. lv/rpap/att_plans 
[20]. Vides Konsultāciju Birojs Ltd. Deglava Dump Site Research. 2010 [in Latvian, unpublished]

[21]. Vides Konsultāciju Birojs Ltd. Kleisti Dump Site Research. 2011 [in Latvian, unpublished]

[22]. Landfill Gas Emission Model. Version 3.02. EPA-600/R-05/047 May 2005. Available: http://www.epa.gov/ ttncatc1/dir1/landgem-v302-guide.pdf

[23]. Lombi E., Wenzel W.W.,Adriano D.C.: Soil Contamination, Risk Reduction and Remediation. Land Contamination \& Reclamation, 6 (4), 1998, 183-197.

[24]. Smith, L.A., Means, J.L., Chen, A., Alleman, B., Chapma, C.C., Tixier Jr., J.S., Brauning, S.E., Gavaskar, A.R., Royer, M.D. (1995). Remedial Option for Metals, Contaminated Sites. Lewis, Boca Raton, FL.

[25]. Conca, J.L., Lu, N., Parker G., Moore, B., Adams A., (2000). PIMS - Remediation of Metal Contaminated Waters and Soils. Proceedings of the Second International Conference on Remediation of Chlorinated and Recalcitrant Compounds 